\title{
Differential patterns in luteal prolactin and LH receptors during pregnancy in sows and ewes
}

\author{
H. Jammes, A. Schirar and J. Djiane \\ Laboratoire de Physiologie de la Lactation, INRA-CNRZ, 78350 Jouy-en-Josas, France
}

\begin{abstract}
Summary. In the sow, a dramatic increase of LH specific binding was observed during the second half of pregnancy. This was due to an increase in receptor number $(41 \mathrm{fmol}$ and $95 \mathrm{fmol} / \mathrm{mg}$ protein at Days 50 and 105 respectively). The apparent association constant was unchanged. The pattern of prolactin receptor content showed two peaks at Day 60 and Day 105. Prolactin receptors increased earlier during pregnancy than did LH receptors, suggesting a possible role of prolactin in the induction of $\mathrm{LH}$ receptors.

In the ewe, the receptor content of LH and prolactin did not change very much during pregnancy. The corpus luteum showed normal luteal function until parturition although it was not necessary for maintenance of pregnancy in the ewes.
\end{abstract}

\section{Introduction}

Ziecik, Shaw \& Flint (1980) analysed LH receptor levels in luteal membranes during the oestrous cycle and early pregnancy in the sow and demonstrated that a rapid increase of the receptors occurred around Day 30 of pregnancy, Prolactin receptors showed an important increase during the same period (Rolland, Gunsalus \& Hammond, 1976). The corpus luteum is absolutely necessary for maintenance of pregnancy during the entire pregnancy period in the sow (Du Mesnil du Buisson, 1973).

In the ewe, the corpus luteum is required for the maintenance of pregnancy only during the first 50 days (Denamur \& Martinet, 1955); after that, the placenta is responsible for the major part of progesterone secretion. $\mathrm{LH}$ receptors have been characterized and the profiles of their binding capacities analysed during the oestrous cycle and early pregnancy; some changes in binding capacity were observed (Diekman, Callaghan, Nett \& Niswender, 1978). To our knowledge, no work has been published on prolactin receptor profiles of sheep corpora lutea.

The aim of the present study was to describe comparative changes in prolactin and LH receptors in the sow and ewe throughout pregnancy when the corpus luteum function is of relatively different importance in the two species. In addition, we have analysed changes in the receptors for placental lactogen hormone in the ewe. The presence of these receptors has been demonstrated (Chan, Robertson \& Friesen, 1978) and they appear to possess a binding specificity different from that of prolactin receptors. A similar hormone has not yet been identified in the sow (Kelly, Tsushima, Shiu \& Friesen, 1976).

\section{Materials and Methods}

Membrane preparation. Corpora lutea, collected from Large White sows (25 animals) and Prèalpesdu-Sud ewes ( 25 animals) at different stages of pregnancy, were trimmed, weighed, minced on an ice-bed and homogenized in ice-cold $0.3 \mathrm{M}$-sucrose using a Polytron homogenizer at medium speed for $30 \mathrm{sec}$. The ratio of tissue to sucrose was $1: 5(\mathrm{w} / \mathrm{v})$. The homogenate was filtered through a nylon strainer $(64 \mu \mathrm{m})$ and centrifuged at $200 \mathrm{~g}$ for $20 \mathrm{~min}$ and the supernatant was centrifuged at 100000 $\boldsymbol{g}$ for $20 \mathrm{~min}$. The resulting pellet was suspended in $3 \mathrm{ml}$ ice-cold $25 \mathrm{~mm}$-Tris- $\mathrm{HCl}, \mathrm{pH} 7 \cdot 4$, 
containing $10 \mathrm{~mm}-\mathrm{MgCl}_{2}$ and was stored at $-80^{\circ} \mathrm{C}$ until assayed. A fraction of the membrane preparation was assayed for protein by the method of Lowry, Rosebrough, Farr \& Randall (1951). The resulting supernatant of ewe luteal membranes was stored at $-20^{\circ} \mathrm{C}$ and a fraction was assayed for progesterone content by radioimmunoassay.

Receptor assay procedure. The LH receptor contents of the corpus luteum membranes from sows and ewes were determined by measuring the specific binding of ${ }^{125}$-labelled hCG (CR $119 \mathrm{NIH}$, 11600 i.u.). Previous studies have shown that LH and hCG bind to the same receptor sites, with similar apparent association constants (Channing \& Kammerman, 1973; Diekman et al., 1978; Ziecik et al., 1980).

The prolactin receptor contents were characterized in sows by ${ }^{125} \mathrm{I}$ - labelled ovine prolactin (PS $13,30 \mathrm{i} . \mathrm{u} . / \mathrm{ng}$ ) and in sheep by ${ }^{125} \mathrm{I}$-labelled ovine prolactin and ${ }^{125} \mathrm{I}$-labelled human GH (HS 2160 , 2 i.u./mg). Human growth hormone has been shown to have lactogenic activity in the rabbit mammary gland (Forsyth, 1971) and has been used to identify prolactin receptors in a number of target organs (Posner, Kelly, Shiu \& Friesen, 1974; Djiane, Delouis \& Kelly, 1979; Friesen, Shiu, Elsholtz, Simpson \& Hugues, 1982). The major advantages of hGH or hCG for receptor studies consist in their higher resistance and stability during and after labelling by ${ }^{125} \mathrm{I}$. These various hormones and ovine placental lactogen, which was kindly provided by Dr H. G. Friesen, were iodinated using chloramine T by the method of Greenwood, Hunter \& Glover (1963), and the labelled hormones were purified on an AcA 54 ultrogel column. Specific activities of resulting tracers ranged between 70 and $90 \mu \mathrm{Ci} / \mu \mathrm{g}$.

Assay procedure. Binding studies were conducted with $200 \mu \mathrm{g}$ membrane protein in triplicate. Incubations were performed overnight at room temperature in a total volume of $0.5 \mathrm{ml}(25 \mathrm{~mm}$ Tris- $\mathrm{HCl}, \mathrm{pH} \mathrm{7.4,} 10 \mathrm{~mm}-\mathrm{MgCl}_{2}$ containing $0.1 \% \mathrm{BSA}$ ). The membranes were incubated in Tris buffer with $10^{5}$ c.p.m. ${ }^{125} \mathrm{I}$-labelled ovine prolactin or ${ }^{125} \mathrm{I}$-labelled $\mathrm{hGH}$, or with $10^{4}$ c.p.m. ${ }^{125} \mathrm{I}$ labelled hCG or ${ }^{125} \mathrm{I}$-labelled ovine placental lactogen. Non-specific binding, determined in the presence of a large excess of unlabelled hormone $(2 \mu \mathrm{g} / \mathrm{ml})$, was usually less than $5 \%$ of the total radioactivity added. The incubations were stopped with $3 \mathrm{ml}$ of ice-cold Tris buffer. Bound and free labelled hormones were separated by centrifugation at $5000 \mathrm{~g}$ at $4^{\circ} \mathrm{C}$ for $30 \mathrm{~min}$. The supernatant was decanted by aspiration and the radioactivity of membrane pellets was determined using an LKB autogamma counter.

The number of LH receptors in sow corpora lutea and their apparent association constant $\left(K_{\mathrm{a}}\right)$ were measured at equilibrium. The saturation curve was plotted with 10 different concentrations of unlabelled hCG in the $0-100 \mathrm{ng} / \mathrm{ml}$ range and with a constant amount of ${ }^{125} \mathrm{I}$-labelled hCG $\left(10^{4}\right.$ c.p.m.). The binding characteristics were determined by Scatchard analysis of the saturation curve data.

Hormone assay. Plasma and luteal progesterone concentrations were determined after extraction in one assay by radioimmunoassay, using tritiated progesterone $\left(\left[1,2,6,7-{ }^{3} \mathrm{H}\right]-\right.$ progesterone; sp. act. $80 \mu \mathrm{Ci} / \mathrm{nmol}$, Amersham Int., Bucks., U.K.) and a specific antiprogesterone antibody (obtained by injection of $11 \alpha$-hemisuccinate-progesterone in rabbits). Assay sensitivity was $0.2 \mathrm{ng} / \mathrm{ml}$ and the intra-assay coefficient of variation was $<5 \%$.

Statistics. The data were statistically compared by the multirange Duncan-Krammer test. Differences were considered significant when $P \leqslant 0.01$.

\section{Results}

Sow

The weight of the corpus luteum increased rapidly during the first 10 days of pregnancy and remained unchanged until parturition when, as expected, a decrease was observed (Text-fig. 1a). 

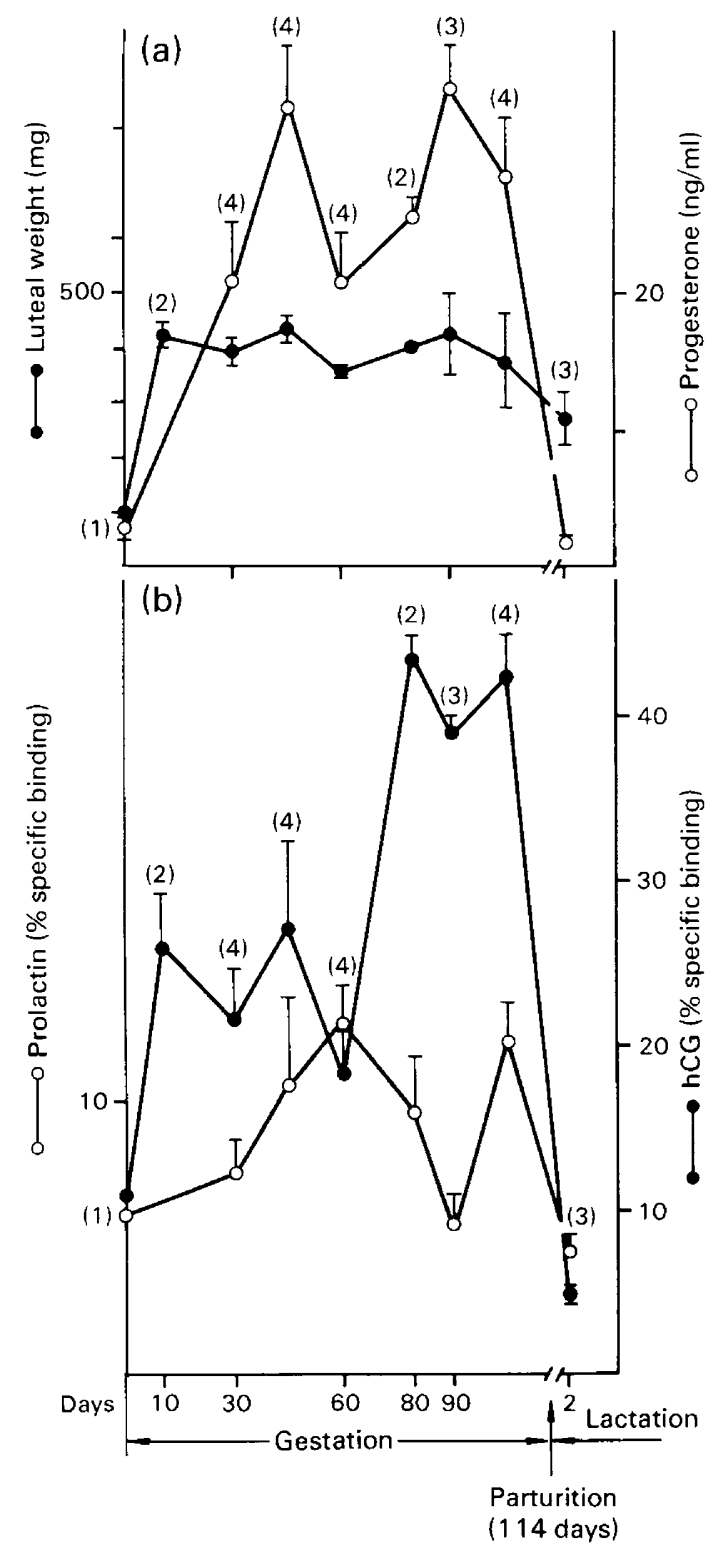

Text-fig. 1. Changes in (a) luteal wet weight, plasma progesterone concentration and (b) the specific binding of ${ }^{125} \mathrm{I}$-labelled $\mathrm{hCG}$ and ${ }^{125} \mathrm{I}$-labelled prolactin in corpus luteum membranes of sows during pregnancy. Each point is the mean \pm s.e.m. from 2-4 determinations (no. of animals in parentheses). In each animal the binding assay was performed in triplicate. Specific binding was expressed as a percentage of total radioactivity added to the incubation medium (usually $9 \times 10^{4}$ c.p.m. for ${ }^{125} \mathrm{I}$-labelled hCG and $10^{5}$ c.p.m. for ${ }^{125} \mathrm{I}$-labelled ovine prolactin). Non-specific binding was obtained with a large excess of unlabelled hormone $(2 \mu \mathrm{g} / \mathrm{ml})$. See 'Materials and Methods' for other details.

Blood plasma progesterone concentrations were high throughout pregnancy, but decreased significantly at Day 60 (Text-fig. 1a). Because the corpus luteum alone is responsible for progesterone synthesis in the sow, the pattern of plasma progesterone levels was a good index of luteal secretory activity. 
Text-figure 1 (b) shows the changes in prolactin and $\mathrm{LH}$ receptor concentrations in membrane preparations obtained from sow corpora lutea at different stages of pregnancy and just after parturition. Prolactin receptors increased linearly until Day 60 of pregnancy $(P<0.01$ between Days 0 and 60), after which a temporary decrease was observed before the level rose sharply around Day 105 of pregnancy. The mean of specific prolactin binding at Days 60 and 105 of pregnancy was $37.2 \pm 4.41 \mathrm{fmol} / \mathrm{mg}$ protein (determination in triplicate from 10 animals). After parturition, the prolactin receptors decreased rapidly.

LH binding also increased during the first 10 days of pregnancy and then, after a short period during which the receptors remained constant or decreased slightly (Days 45-60), a dramatic increase was observed $(P<0.01)$ between Day 60 and Days 80,90 and 105 . Just after parturition, $\mathrm{LH}$ binding was undetectable. The increase of $\mathrm{LH}$ binding could have been due to variations in receptor number or receptor $\mathrm{LH}$ affinity. To test these possibilities, the number of $\mathrm{LH}$ receptors and the apparent association constant $\left(K_{\mathrm{a}}\right)$ of $\mathrm{LH}$-receptor interaction were evaluated at two stages of pregnancy (Days 50 and 105). Several saturation curves were plotted from experiments with the corpus luteum membranes from both stages and transformed by Scatchard analysis. Text-figure 2 shows the results of one experiment, carried out on a pool of luteal tissue collected at Day 50 and on pooled luteal tissue collected at Day 105 . The incubations were performed with $200 \mu$ g protein and normalized LH binding site concentrations were calculated to be $41 \mathrm{fmol} / \mathrm{mg}$ protein and 95 $\mathrm{fmol} / \mathrm{mg}$ protein at Days 50 and 105, respectively. The apparent association constants were $1 \times$ $10^{11} \mathrm{M}^{-1}$ and $4.7 \times 10^{11} \mathrm{M}^{-1}$, respectively.
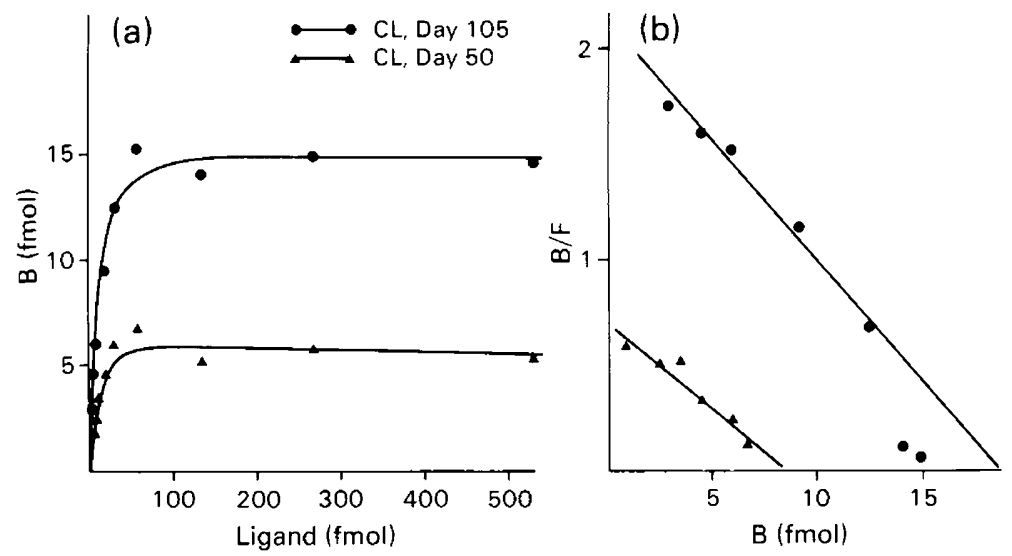

Text-fig. 2. Determination of binding affinity and numbers of binding sites in sow corpora lutea at Days 50 and 105 of pregnancy. These experiments were carried out on pooled membranes of corpora lutea at 2 stages of gestation ( 3 animals per group). (a) A constant amount of membranes $\left(200 \mu \mathrm{g} /\right.$ protein) was incubated with a constant amount of ${ }^{125} \mathrm{I}$-labelled hCG $(10000$ c.p.m.) and increasing concentration of unlabelled hCG $(0-100 \mathrm{ng} / \mathrm{ml})$. The resulting competition curves were converted into saturation curves. Each point is the mean of triplicate determinations. (b) The transformation of saturation curves by the method of Scatchard.

Progesterone concentration decreased at Day 60 as did LH receptor content but the entire luteal function was restored at Day 80 of pregnancy, when $\mathrm{LH}$ receptors also showed a dramatic increase. The major changes in receptor content therefore occurred when corpus luteum weight remained constant, suggesting that they were not due to modifications in the cell population number; this fact is in agreement with the usual absence of mitosis in the corpus luteum. 

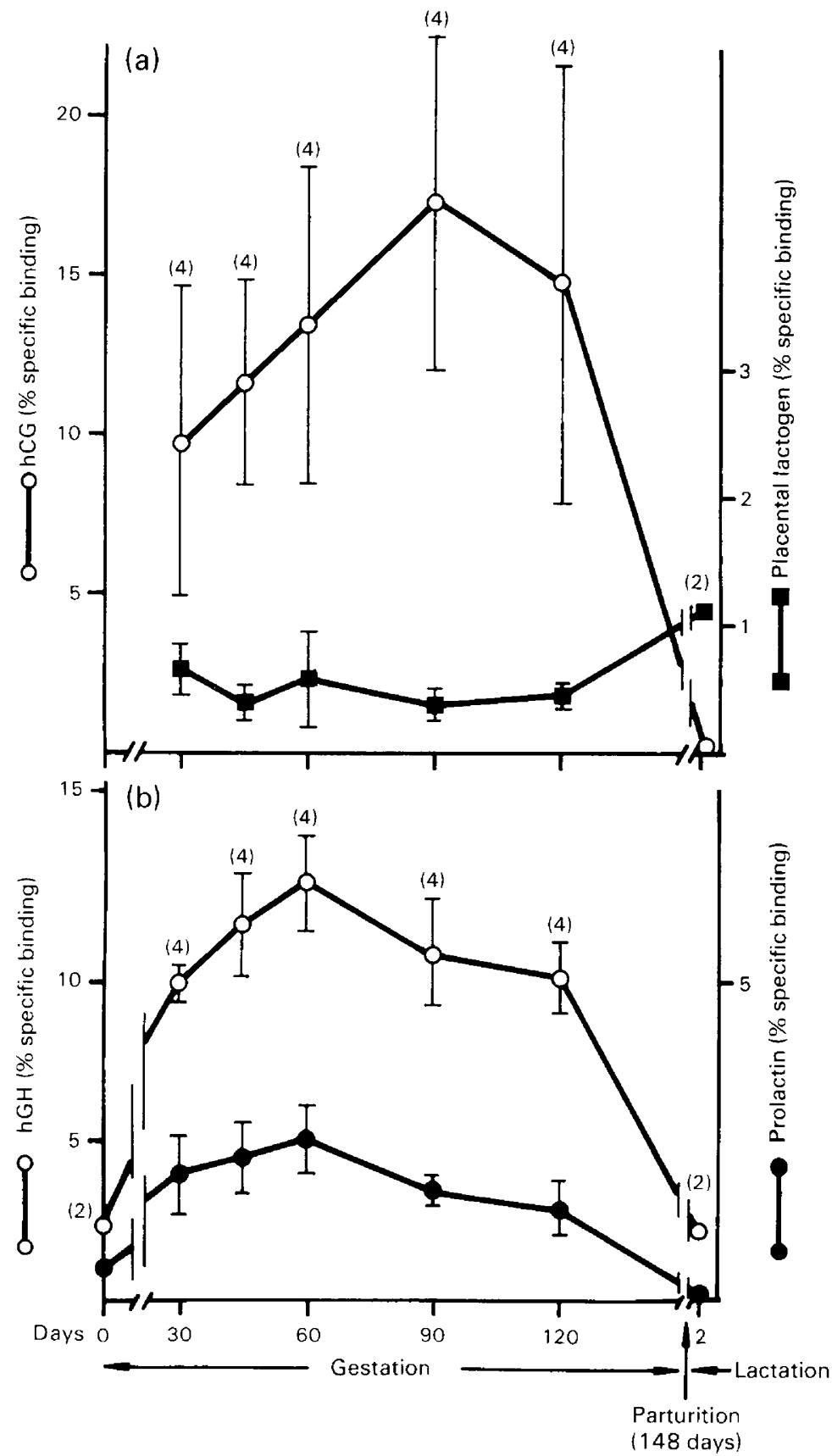

Text-fig. 3. Changes in the specific binding of hormones in the corpora lutea of ewes during pregnancy. (a) ${ }^{125} \mathrm{I}$-labelled hCG and ${ }^{125} \mathrm{I}$-labelled ovine placental lactogen. The non-specific binding was determined in the presence of a large excess of unlabelled hormone. Each point is the mean \pm s.e.m. for the no. of animals indicated in parentheses and each binding assay was performed in triplicate for one animal. See 'Materials and Methods' for other details. (b) Changes in prolactin receptors titrated by specific binding of ${ }^{125} \mathrm{I}$-labelled ovine prolactin and ${ }^{125} \mathrm{I}$-labelled $\mathrm{hGH}$. The non-specific binding was determined in the presence of a large excess of unlabelled ovine prolactin $(2 \mu \mathrm{g} / \mathrm{ml})$. 
Ewe

Changes in LH and placental lactogen receptors during pregnancy are shown in Text-fig. 3(a). LH receptors increased linearly from Days 30 to 90 of pregnancy and were maintained until parturition. The corpus luteum was completely regressed on Day 2 post partum and LH binding was very low. These values varied greatly from one animal to another, as shown by the large standard error, and the increase in binding between early and late pregnancy was not significant. This heterogeneity between animals was shown previously by Niswender, Reimers, Diekman \& Nett (1976). Ovine placental lactogen bound to corpus luteum membranes (Text-fig. 3a) but binding remained very low (between 0.5 and $1 \%$ ) throughout pregnancy. Although this binding was low, it appeared to be specific since ${ }^{125} \mathrm{I}$-labelled prolactin was unable to compete with unlabelled placental lactogen, confirming the results of Chan et al. (1978). We did not test the interaction of ovine GH on the binding of ovine placental lactogen.

When prolactin receptors were titrated using ${ }^{125}$ I-labelled ovine prolactin as the radioactive ligand in the presence or absence of unlabelled ovine prolactin, their levels remained very low and did not change throughout pregnancy (Text-fig. $3 \mathrm{~b})$. The binding values $(7.5 \pm 0.45 \mathrm{fmol} / \mathrm{mg}$ protein) were 5 times lower in ewe than in sow corpora lutea and could be related to a particular requirement of the prolactin receptor in the ewe in terms of the nature of the ligand. In fact, when prolactin receptors were titrated using ${ }^{125} \mathrm{I}$-labelled $\mathrm{hGH}$, and displaced by unlabelled ovine prolactin, changes were detected (Text-fig. 3b). Specific binding of ${ }^{125} \mathrm{I}$-labelled hGH showed a 6fold increase during the first half of pregnancy $(P<0.001)$ between Days 0 and 60 . This increase preceded that of $\mathrm{LH}$ receptors and was more evident than in sow corpora lutea. During the second half of pregnancy in the ewe, prolactin receptors were constant and decreased at the time of parturition. This pattern was different from that in sow corpora lutea in which a second peak of prolactin receptors was observed in late pregnancy (Text-fig. 1b). Corpus luteum weight increased during early pregnancy and then remained constant throughout pregnancy (Text-fig. 4). Progesterone content (Text-fig. 4) was maintained at a high level until parturition, suggesting that the corpus luteum was functional during the entire pregnancy.

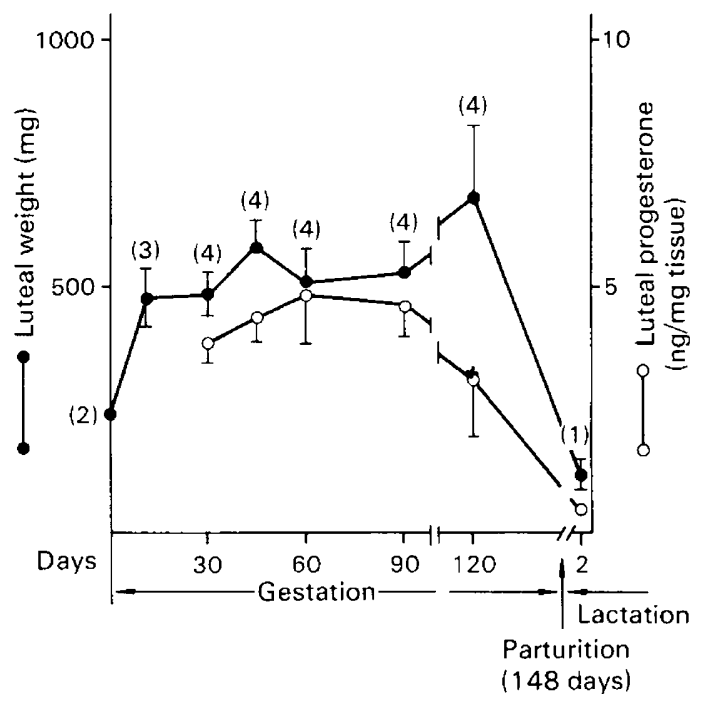

Text-fig. 4. Changes in luteal wet weight and luteal content of progesterone in the ewe during pregnancy. Each point is the mean \pm s.e.m. for the no. of animals indicated in parentheses. 


\section{Discussion}

The results presented here emphasize that there are large quantitative differences in gonadotrophic hormone receptors between sheep and pigs. LH and prolactin receptors were found in much higher concentrations in the corpus luteum membranes of the sow. Plasma prolactin levels during pregnancy are much higher in ewes (10-50 ng/ml: Kann \& Denamur, 1974) than in sows ( $7 \mathrm{ng} / \mathrm{ml}$ : Dusza \& Krzymowska, 1981).

In the sow, the plasma level of LH in early and mid-pregnancy is comparable to its concentration in the mid-luteal phase of the oestrous cycle $(4.5 \mathrm{ng} / \mathrm{ml})$, but the LH pulses occurring in the second half of pregnancy are less numerous and of a lower amplitude (Ziecik, Tilton, Weigh \& Williams, 1982/1983). In the ewe, the LH concentrations in the blood during early pregnancy are low (Niswender, Roche, Foster \& Midgley, 1968). During late pregnancy, it is likely that they follow a similar pattern to those in the sow.

The characteristics of prolactin receptors appear to be different in the two species: ${ }^{125} \mathrm{I}$-labelled ovine prolactin and hGH are equipotent tracers for the measurement of prolactin receptors in sow mammary gland (results unpublished), whereas ${ }^{125}$ I-labelled $\mathrm{hGH}$ appears to be the more adequate tracer for labelling prolactin receptors in sheep-a paradox which has been noted by Servely et al. (1983), who studied the specificity of prolactin receptors in sheep mammary gland. This observation cannot be easily explained, but it may be due to an alteration of the prolactin molecule after iodination. In spite of the lower binding of ${ }^{125} \mathrm{I}$-labelled ovine prolactin, the presence of such receptors is without question. However, to analyse receptor modulations with accuracy, it was easier to use ${ }^{125} \mathrm{I}$-labelled $\mathrm{hGH}$ : the non-specific binding was determined with unlabelled ovine prolactin.

In accord with previous published work (Rolland et al., 1976; Ziecik et al., 1980) we have shown here that $\mathrm{LH}$ and prolactin receptors increase during the first 30 days of pregnancy in the sow but that the major increase in receptor content appears at 60 days for prolactin and 80 days for $\mathrm{LH}$ receptors. The present findings for sows demonstrate that there is a relationship between $\mathrm{LH}$ receptor content and corpus luteum responsiveness. Therefore, in studying the formation of the hormone-receptor complex, it is very important to know the concentration of endogenous hormones in the blood plasma and the number of their hormone receptors. LH receptor number in the sow corpus luteum follows a biphasic pattern: during the first half of pregnancy, when the plasma LH concentrations are similar to those observed during mid-luteal phase, the receptor content is stable; it then increases when the LH concentration decreases. Optimal concentration of the hormone-receptor complex might be thus obtained and luteal function maintained. These observations are in good agreement with what is known about the differential necessity of the corpus luteum for maintenance of pregnancy. The same is true for prolactin receptors which show a second increase during late pregnancy in the sow. This second increase in LH and prolactin receptors suggests that the sow corpus luteum is highly sensitive to circulating levels of these hormones and might even increase the receptivity of the corpus luteum to $\mathrm{LH}$ and prolactin in the second half of pregnancy. The augmentation in LH and prolactin receptors could permit optimal progesterone secretion until parturition. These results may explain why it is possible to section the pituitary stalk at Day 70 of pregnancy without causing abortion (Du Mesnil du Buisson, 1973). In this case, the sow corpus luteum appears to have more $\mathrm{LH}$ and prolactin receptors and to be capable of detecting residual hormonal concentrations which are frequently observed after this surgical operation (Bryant, Greenwood, Kann, Martinet \& Denamur, 1971), and of secreting progesterone until parturition.

The increase in $\mathrm{LH}$ and prolactin receptors during pregnancy may be due to different hormonal regulation. In the present work, the prolactin receptors increased earlier during pregnancy than did the $\mathrm{LH}$ receptors. This was more evident in the sow corpus luteum, suggesting a possible regulatory role of prolactin in the induction of LH receptors, as demonstrated by Richards \& Williams (1976) for rat granulosa cells, and by Holt, Richards, Midgley \& Reichert (1976) for rat luteal cells. 
Placental secretion, and particularly that of oestrogens, may play a crucial role in the increase of LH receptors. Oestrogens, which are luteotrophic in the intact sow (Kidder, Casida \& Ruimmer, 1955; Gardner, First \& Casida, 1963), are produced by the placenta in this species and increase at Days 25 and 70 (Fèvre, Leglise \& Rombauts, 1968). However, the mechanisms involved in this response are not clear. Oestrogens increase progesterone secretion by sow granulosa cells in vitro (Goldenberg, Bridson \& Kohler, 1972) and stimulate ${ }^{125}$ I-labelled LH binding to dispersed granulosa cells (Nakano, Akahori, Katayama \& Tojo, 1977) and luteal membranes (Garverick, Polge \& Flint, 1982) in the sow. Oestrogens also play a role in prolactin receptor regulation, as demonstrated in pig granulosa cells at the time of luteinization (Hammond \& Krall, 1979). The mechanism of oestrogen regulation is unknown, but it can be concluded from these studies that oestrogens may have a direct effect on the corpus luteum and on $\mathrm{LH}$ and/or prolactin receptor content in sows.

The pituitary gonadotrophins (LH and prolactin) are important regulators of corpus luteum progesterone biosynthesis but other hormonal regulation, and in particular placental hormones, can be involved in the secretory function. A lactogenic hormone of placental origin (placental lactogen) has been identified in sheep (Handwerger, Maurer, Barrett, Hurley \& Fellows, 1974); this hormone presents a low and stable binding during pregnancy which is independent of prolactin receptor concentrations (Chan et al., 1978). The results described above suggest that ovine placental lactogen may have a direct action on luteal cells since this hormone binds to luteal membranes. Although ovine placental lactogen has no acute action on the progesterone secretion of dispersed luteal cells (Rodgers, O'Shea \& Findlay, 1983), it may have a long-term effect on the overall functions of these cells in facilitating their responses to LH and prolactin.

We thank Dr J. Martinet for helpful advice; Professor $\mathrm{H}$. Clauser for assistance in the preparation of the manuscript; Dr H. G. Friesen (Winnipeg, Canada) for the ovine placental lactogen; and the National Institute of Health (NIH) for the other purified hormones.

\section{References}

Bryant, G.D., Greenwood, F.C., Kann, G., Martinet, J. \& Denamur, R. (1971) Plasma prolactin in the oestrous cycle of the ewe: effect of pituitary stalk section. $J$. Endocr. 51, 405-406.

Chan, J.S.D., Robertson, H.A. \& Friesen, H.G. (1978) Distribution of binding sites for ovine placental lactogen in the sheep. Endocrinology 102, 632-640.

Channing, C.P. \& Kammerman, S. (1973) Characteristics of gonadotropin receptors of porcine granulosa cells during follicle maturation. Endocrinology 92, 531540 .

Denamur, R. \& Martinet, J. (1955) Effets de l'ovariectomie chez la brebis pendant la gestation. C. r. hebd. Séanc. Acad. Sci., Paris D 149, 2105-2107.

Diekman, M.A., Callaghan, P.O., Nett, T.M. \& Niswender, G.D. (1978) Validation of methods and quantification of luteal receptors for $\mathrm{LH}$ throughout the estrous cycle and early pregnancy in ewes. Biol. Reprod. 19, 999-1009.

Djiane, J., Delouis, C. \& Kelly, P.A. (1979) Prolactin receptors in organ culture of rabbit mammary gland: effect of cycloheximide and prolactin (40678). Proc. Soc. exp. Biol. Med. 162, 342-346.

Du Mesnil du Buisson, F. (1973) Facteurs lutéotropes chez la truie. In Le Corps Jaune, pp. 225-237. Eds R. Denamur \& A. Netter. Masson, Paris.
Dusza, L. \& Krzymowska, H. (1981) Plasma prolactin levels in sows during pregnancy, parturition and early lactation. J. Reprod. Fert. 61, 131-134.

Fèvre, J., Leglise, P.C. \& Rombauts, P. (1968) Rôle de l'hypophyse et des ovaires dans la biosynthèse des oestrogènes au cours de la gestation chez la truie. Annls Biol. anim. Biochem. Biophys. 8, 225-233.

Forsyth, I.A. (1971) Organ culture techniques and study of hormone effects on the mammary gland. $J$. Dairy Res. 3, 419-444.

Friesen, H.G., Shiu, R.P.C., Elsholtz, H., Simpson, S. \& Hugues, J. (1982) Prolactin and growth hormone receptors. In Receptors, Antibodies and Disease (Ciba Fdn Symp. No. 90), pp. 263-278. Pitman, London.

Gardner, M.L., First, N.L. \& Casida, L.E. (1963) Effect of exogenous estrogens on corpus luteum maintenance in gilts. J. Anim. Sci. 22, 132-134.

Garverick, H.A., Polge, C. \& Flint, A.P.F. (1982) Oestradiol administration raises luteal $\mathrm{LH}$ receptor levels in intact and hysterectomized pigs. $J$. Reprod. Fert. 66, 371-377.

Goldenberg, R.L., Bridson, W.E. \& Kohler, P.O. (1972) Estrogen stimulation of progesterone synthesis by porcine granulosa cells in culture. Biochem. Biophys. Res. Commun. 48, 101-107.

Greenwood, F., Hunter, W. \& Glover, J. (1963) The 
preparation of jodine 131 labelled human growth hormone of high specific radioactivity. Biochem. $J$. 89, 114-123.

Hammond, J.M. \& Krall, E. (1979) Steroid hormones modulate prolactin binding by cultured porcine granulosa cells. Biochem. Biophys. Res. Commun. 91, 284-288.

Handwerger, S., Maurer, W., Barrett, J., Hurley, T. \& Fellows, R.E. (1974) Evidence for homology between ovine and human placental lactogens. Endocr. Res. Commun. 1, 403-413.

Holt, J.A., Richards, J.S., Midgley, A.R., Jr \& Reichert, L.E., Jr (1976) Effect of prolactin on LH receptor in rat luteal cells. Endocrinology 98, 1005-1013.

Kann, G. \& Denamur, R. (1974) Possible role of prolactin during the oestrous cycle and gestation in the ewe. $J$. Reprod. Fert. 39, 473-483.

Kelly, P.A., Tsushima, T., Shiu, R.P.C. \& Friesen, H.G. (1976) Lactogenic and growth hormone-like activities in pregnancy determined by radioreceptor assay. Endocrinology 99, 765-773.

Kidder, H.E., Casida, L.E. \& Ruimmer, K.H. (1955) Some effects of estrogen injections on the estrual cycle of gilts. J. Anim. Sci. 14, 470-474.

Lowry, O.H., Rosebrough, N.J., Farr, A.L. \& Randall, R.J. (1951) Protein measurement with the folin phenol reagent. J. biol. Chem. 193, 265-275.

Nakano, R., Akahori, T., Katayama, K. \& Tojo, S. (1977) Binding of LH and FSH to porcine granulosa cells during follicular maturation. J. Reprod. Fert. 51, 2327.

Niswender, G.D., Roche, J.F., Foster, D.L. \& Midgley, A.R., Jr (1968) Radioimmunoassay of serum levels of luteinizing hormone during the cycle and early pregnancy in the ewe. Proc. Soc. exp. Biol. Med. 129, 901-904.

Niswender, G.D., Reimers, T.J., Diekman, M.A. \& Nett, T.M. (1976) Blood flow: a mediator of ovarian function. Biol. Reprod. 14, 64-81.

Posner, B.I., Kelly, P.A., Shiu, R.P.C. \& Friesen, H.G. (1974) Studies of insulin, growth hormone and prolactin binding: tissue distribution, species variation and characterization. Endocrinology 95, 521531 .

Richards, J.S. \& Williams, J.J. (1976) Luteal cell receptor content for prolactin (PRL) and luteinizing hormone (LH): regulation by LH and PRL. Endocrinology 99, 1571-1581.

Rodgers, R.J., O'Shea, J.D. \& Findlay, J.K. (1983) Progesterone production in vitro by small and large ovine luteal cells. J. Reprod. Fert. 69, 113-124.

Rolland, R., Gunsalus, G.L. \& Hammond, J.M. (1976) Demonstration of specific binding of prolactin by porcine corpora lutea. Endocrinology 98, 1083-1091.

Servely, J.L., N'Guema Emane, M., Houdebine, L.M., Djiane, J., Delouis, C. \& Kelly, P.A. (1983) Comparative measurement of the lactogenic activity of ovine placental lactogen in rabbit and ewe mammary gland. Gen. comp. Endocr. 51, 255-262.

Ziecik, A., Shaw, H.J. \& Flint, A.P.F. (1980) Luteal LH receptors during the oestrous cycle and early pregnancy in the pig. $J$. Reprod. Fert. 60, 129-137.

Ziecik, A., Tilton, J.E., Weigh, R. \& Williams, G.L. (1982/1983) Plasma luteinizing hormone during pregnancy in the pig. Anim. Reprod. Sci. 5, 213-218.

Received 29 February 1984 